\title{
Was the Huey Cocoliztli a Haemorrhagic Fever?
}

\author{
JOHN S MARR and JAMES B KIRACOFE*
}

\begin{abstract}
Introduction
Following the five hundredth anniversary of Columbus's arrival in the New World, interest has intensified in the various consequences of the resulting inter-continental contact. Among the many things that Europeans brought to America were Old World diseases. As we will see, even the most recent and comprehensive scholarship in the field insists that the catastrophic demographic collapse of the native population of the continent was a result of imported diseases, including, most famously, smallpox, measles, and typhus. While there is surely compelling evidence that Old World epidemic disease devastated the native population, we believe that two of the most deadly outbreaks of the sixteenth century, 1545-48 and 1576-80, may have been of a disease of New World origin.

The 1576-80 epidemic marked a turning point in the development of Mexican culture and of Spanish/Indian relations. During the sixty odd years after initial contact in 1518 the pristine Mesoamerican high culture had been dismantled. Taken apart stone by stone, it was transformed, and with the same stones rebuilt into something never seen before. In one of the greatest building programmes ever recorded, a new sacred landscape was created in Mexico, marked now by hundreds of churches, great and small, rather than by the pyramids and temple platforms of old. By the third generation after contact few still remembered the world as it had been before the coming of the Spaniards. Yet though there was naturally a persistence of the old ways, there was also

* John S Marr, MD, MPH, Senior Lecturer, Department of International Medicine, New York Medical College Graduate School of Health Sciences, Valhalla, New York 10595, USA. James B Kiracofe, PhD, Director, Inter-American Institute for Advanced Studies in Cultural History, PO Box \# 93, Free Union, VA 22940 , USA. Address for correspondence: John S Marr, MD, 22 Lia Fail Way, Cos Cob, CT 06807, USA; e-mail: jsmarr@javanet.com.

We should like to thank William O Autry, PhD, Goshen College, Indiana, Michael D Bowen, PhD, Special Pathogens Branch, Centers for Disease Control, John T Cathey, MPH, Curtis D Malloy, MPH, Robert McCaa, PhD, University of Minnesota, for their criticisms and helpful

comments on earlier drafts of this article; Charles $\mathrm{H}$ Calisher, PhD, Arthropod-borne and Infectious Diseases Laboratory, Colorado State University, for fine-tuning the virological citations; Mark Engstrom, PhD, Royal Ontario Museum, for his assistance in locating texts on Mexican mammals; Helen H Marr, MFA, for her scrupulous editing of the MS; Prof. Humberto Rodríguez-Camilloni, Virginia Polytechnic Institute and State University, for his help with the translation of the Hernández excerpt; Prof. Robert E Shope, MD, University of Texas (Galveston) for his expert observations on viruses and their history; and Myron G Schultz, DVM, $\mathrm{MD}$, for his continuing support, suggestions and encyclopedic knowledge of the history of infectious diseases.
\end{abstract}




\section{John S Marr and James B Kiracofe}

an acceptance, often enthusiastic, of the new. Everything about daily life had been transformed, from food to clothing to building techniques. Even the sacramental imagination was illuminated with new figures and stories from the new religion. Certainly the policies of the Spanish colonial regime were harsh in many ways, but no more so than those of the Aztec imperial regime had been. By the third generation of Spanish rule the native population was settling into a new way of life in newly built towns and villages expressing fresh ideas about urbanized life. At the very moment when this hard won fusion of European and Mesoamerican cultures seemed ready to emerge from the difficult struggles of its formative period, the disastrous pandemic of 1576-80 struck and carried away the hopeful beginnings of some positive outcomes of inter-cultural contact in early colonial Mexico.

In the end it was neither political policy nor religious ideology, but rather microbial epidemic disease that was the arbiter of cultural transmission and transformation. In the aftermath of the holocaust of 1576-80, the severely weakened native peoples continued to suffer famine and further disease outbreaks. For the rest of the century and into the first decades of the next, the population continued to decline, while the Indians who survived were confronted with the additional burden of steadily increasing numbers of colonists, both Creole and Spanish. As a direct consequence of the epidemic, life for the dwindling Indian population became far more difficult as the Spanish regime, accustomed to the once abundant pool of native labour, sought to maintain tribute payments and tax revenues at their former levels by increasingly coercive means. In many areas the towns and villages recently built in anticipation of a brighter future were simply abandoned as their populations withered away. Without doubt, the devastation caused by the disease changed forever the course of history in Mexico.

The epidemic of 1576-80 was sufficiently different in presentation from previous, well described New World epidemic outbreaks to warrant the new name, huey cocoliztli. This outbreak was the worst of ten previous scourges (Table 1). Nahua chroniclers referred to it as the huey cocoliztli (the term matlazahuatl was also used); Spanish observers called it "the great pestilence". Earlier medical historians have speculated on a possible cause, basing their theories on the Spanish and Nahuatl descriptions and knowledge of disease available at the time. Theories have included smallpox (variola major), alastrim (variola minor), measles, dysentery, pneumonia, pleurisy and influenza. Alternative explanations have included epidemic and endemic typhus, spotted fever, pneumonic plague, and yellow fever. ${ }^{1}$ However, with two

\footnotetext{
${ }^{1}$ In 1931 Henry Rose Carter dismissed yellow fever as a cause of the 1576 epidemic, primarily due to climatologic and entomologic (Aedes mosquito) distribution. An Assistant Surgeon General of the United States Health Service at the time, Carter was a recognized expert in yellow fever. Carter thought the issue important enough to devote a chapter on the "negation of information" which suggested yellow fever as a cause of any of the post-contact Mexican outbreaks, although he noted that some of the major epidemics were due to a (non-yellow fever)
}

\begin{abstract}
haemorrhagic fever: "Neither for the period before the Conquest nor thereafter, up to and including 1576-for which time we have very complete data-is there, in either the Nahautl records or in those of the first group of Spanish historians, an account of any sickness which can possibly be considered as yellow fever." Later, Carter cited the epidemics of $1544-45$ and then, the 1576 outbreak: "It is called 'peste', 'pestilencia', 'mortalidad', 'epidemia', 'cocoliztle', and 'matlatotonqui' by them... This 'matlazahuatl' has always been surrounded with
\end{abstract}




\section{Was the Huey Cocoliztli a Haemorrhagic Fever?}

exceptions, plausible explanations for the huey cocoliztli are lacking. In 1933 Charles Nicolle, the French winner of the Nobel Prize for medicine in 1928, published a book on the historical influence of infectious diseases. He dismissed typhus as the cause of the 1576 epidemic and stated that it was due to smallpox. ${ }^{2}$ In 1935, an American bacteriologist, Hans Zinsser, took a different view, concluding that the disease was indeed typhus. ${ }^{3}$ Since their writings subsequent medical historians have deferred to these experts. ${ }^{4}$

We reviewed Nicolle's and Zinsser's work and the documents available to them when they were writing. We read translations of Nahuatl codices and other newly accessed information. We studied a recent publication on Mexican rodents and mammalian bionomics. We considered recent phylogenic hypotheses and the epidemiology of New World (Tacaribe) arenaviral diseases. We reviewed historical and anthropological data describing post-contact Aztec agrarian practices. We examined published codices graphically illustrating the symptoms. We carefully summarized and compared the symptomatology of smallpox, typhus and New World haemorrhagic fevers. Based on this study we now conclude that the huey cocoliztli may have been a haemorrhagic fever. We suggest that this hypothesis should be considered by anthropologists, virologists and epidemiologists.

mystery, some considering it yellow fever; but more generally it was believed to have been a disease indigenous and peculiar to the Mexican highlands and to which Europeans were not subject. If there was such a disease, from time to time epidemic there, characterized by vomiting of blood and other hemorrhages, it has

disappeared". Henry Rose Carter, Yellow fever: an epidemiological and historical study of its place of origin, ed. L A Carter and W H Frost, Baltimore, Williams \& Wilkins, 1931, pp. 96, 106-7.

${ }^{2}$ Charles J Nicolle, Destin des maladies infectieuses, Paris, Libraire Félix Alcan, 1933, p. 156.

${ }^{3}$ Hans Zinsser, Rats, lice and history, Boston, Little, Brown, for Atlantic Monthly Press, 1935, new edition, 1963.

${ }^{4} \mathrm{~A}$ number of other medical history books cite either smallpox or typhus as the cause of many, if not all, post-contact epidemics. For example: Arturo Castiglioni, A history of medicine, New York, Alfred A Knopf, 1947, pp. 467-8; David E Stannard, American holocaust: Columbus and the conquest of the New World, Oxford University Press, 1992, p. 81; George C Kohn (ed.), Encyclopedia of plague and pestilence, New York, Facts on File, 1995, p. 208; Jared Diamond, Guns, germs and steel, New York, W W Norton,1997, p. 210; Sheldon Watts, Epidemics and history, New Haven, Yale University Press, 1997, p. 90. Watts does not specifically discuss the $1576-80$ epidemic, citing Lovell's statistics on mortality between 1518-1605. However, Lovell offered a variety of possible explanations for population decline, including smallpox, typhus, plague and measles. He favoured Zinsser's typhus theory (pp. 38-44). See George Lovell, 'Heavy shadows and black night', in The Americas before and after 1492, Current Geographical Research, Annals of the Association of American Geographers, 1992, 82 (3). An important book offering a comprehensive synthetic compilation and a review of scholarship with new insight and interpretation concerning the role of disease in the overall demographic catastrophe of the sixteenth century in the New World is Noble David Cook, Born to die: disease and New World conquest, 1492-1650, Cambridge University Press, 1998. Discarding the possibility of New World contagion, Cook states categorically that "The original source of the 1540s epidemic must have been Old World" (p. 104), he goes on to propose typhus. In his brief discussion of the 1576 outbreak he suggests that the identity of the sickness may be elusive because it was composed of several overlapping illnesses. But, citing a sixteenth-century source, he again points to typhus: "Mendieta identifies the sickness as typhus (tabardillo)" (p. 121). These citations re-affirm our contention that the smallpox-typhus theories have become historical orthodoxy, paradigms largely unquestioned for over fifty years. 


\section{John S Marr and James B Kiracofe}

Table 1

Summary of epidemics occurring in Mexico 1520-1616 by year

\begin{tabular}{|c|c|c|c|c|c|}
\hline YEARS & NAHUATL & SPANISH & ENGLISH & DISEASE & OTHER \\
\hline $1520-21$ & $\begin{array}{c}\text { hueyzahuatl } \\
- \\
-\end{array}$ & $\begin{array}{l}\text { sarampión } \\
\text { lepra } \\
\text { sarna }\end{array}$ & $\begin{array}{c}\text { great zahuatl } \\
- \\
-\end{array}$ & $\begin{array}{l}\text { smallpox } \\
\text { mange }\end{array}$ & - \\
\hline $1531-32$ & $\begin{array}{l}\text { zahuatl } \\
\text { zahuatl tepiton }\end{array}$ & $\begin{array}{l}\text { sarampión } \\
\text { viruela }\end{array}$ & $\begin{array}{l}\text { great zahuatl } \\
\text { small zahuatl }\end{array}$ & $\begin{array}{l}\text { smallpox } \\
\text { measles }\end{array}$ & - \\
\hline 1538 & - & viruela & small zahuatl & alastrim & - \\
\hline $1545-48$ & cocoliztli & tabardillo & pestilence & $?$ & $\begin{array}{l}\text { typhus } \\
\text { plague }\end{array}$ \\
\hline 1550 & - & paperas & mumps & mumps & - \\
\hline 1559 & cocoliztli & - & pestilence & $?$ & - \\
\hline $1563-64$ & $\begin{array}{l}\text { zahuatl } \\
\text { hatlatotonqui }\end{array}$ & $\begin{array}{l}\text { sarampión } \\
\text { "dolores de } \\
\text { costado" }\end{array}$ & $\begin{array}{c}\text { great zahuatl } \\
\qquad-\end{array}$ & $\begin{array}{l}\text { smallpox } \\
\text { pleurisy/ } \\
\text { pneumonia }\end{array}$ & - \\
\hline 1566 & cocoliztli & $\begin{array}{l}\text { "pujamento } \\
\text { sangre" }\end{array}$ & great pestilence & ? & - \\
\hline $1576-80$ & $\begin{array}{l}\text { huey cocoliztli } \\
\text { matlazahuatl }\end{array}$ & - & great pestilence & $?$ & typhus \\
\hline 1590 & tlatlasistli & - & catarrh & influenza & - \\
\hline $1592-93$ & $\begin{array}{c}\text { tlatlasistli } \\
- \\
-\end{array}$ & $\begin{array}{l}\qquad- \\
\text { sarampión } \\
\text { garrotillo }\end{array}$ & $\begin{array}{r}\text { catarrh } \\
- \\
-\end{array}$ & $\begin{array}{l}\text { influenza } \\
\text { measles } \\
\text { croup }\end{array}$ & - \\
\hline $1595-97$ & - & $\begin{array}{l}\text { sarampión } \\
\text { paperas } \\
\text { tabardillo }\end{array}$ & mumps & $\begin{array}{l}\text { smallpox } \\
\text { mumps } \\
\text { typhus }\end{array}$ & - \\
\hline $1601-2$ & cocoliztli & - & - & $?$ & - \\
\hline $1604-7$ & cocoliztli & sarampión & - & diarrhoea & - \\
\hline 1613 & cocoliztli & - & - & $?$ & - \\
\hline $1615-16$ & - & $\begin{array}{l}\text { sarampión } \\
\text { viruela }\end{array}$ & - & $\begin{array}{l}\text { smallpox } \\
\text { measles }\end{array}$ & - \\
\hline
\end{tabular}

Nahuat1/Aztec name, Spanish translation, English translation and postulated diseases. (After Charles Gibson, The Aztecs under Spanish rule, Stanford University Press, 1964, p. 448.) 


\section{Was the Huey Cocoliztli a Haemorrhagic Fever?}

\section{Sixteenth-Century Mexican Epidemics}

Epidemic disease caused a catastrophic demographic collapse throughout the Americas in areas newly colonized by the Spaniards during the sixteenth century. The aboriginal peoples of the Antilles were virtually extinct by 1520 , and a staggering reduction of the inhabitants of the mainland soon followed. In Mexico, a population possibly exceeding 20 million before contact in 1518 fell to just under one million a century later, a 90 per cent decline. ${ }^{5}$ The consensus among social scientists and others who have studied these events has been that Old World diseases (smallpox, measles, typhus) were carried by European invaders and/or slave labourers from Africa. ${ }^{6}$ The first of two most devastating epidemics made its appearance in 1545 as cocoliztli; the second, more virulent and widespread manifestation occurred thirty years later, between 1576 and 1580 . This event, which completely altered and redirected the course of colonial history in Mexico, was known as the huey cocoliztli. ${ }^{7}$

Even though the highly suggestive but scattered and fragmentary nature of the surviving documentary evidence does not permit precise reckoning of the sixteenthcentury demographic decline, a few examples selected from the numerous reports are indicative of the levels of mortality: Tlaxcala was an autonomous pre-Columbian enclave surrounded by hostile Aztec territory, which supported the Spanish-led struggle to overthrow Aztec hegemony. In about 1571 it had an estimated total population of 250,000 , by 1583 this had declined to 120,000 , suggesting a mortality rate of 50 per cent. ${ }^{8}$ Outside the Valley of Mexico, 60,000 deaths were reported in the town of Tepeaca, on the all-important road to the Caribbean port of Vera Cruz, and in Temazcaltepec the mortality rate was 50 per cent. ${ }^{9}$ In the Mixteca Alta of Oaxaca, the epidemic of 1576-80 caused a near total depopulation of many towns, resulting in the forced reorganization of the survivors by the colonial authorities attempting to create viable communities out of the wreckage. ${ }^{10}$

\section{Previous Interpretations}

Nicolle and Zinsser were the first modern medical historians to theorize on the cause of the sixteenth-century Mexican epidemics. ${ }^{11}$ Nicolle believed them to be smallpox, while Zinsser concluded that the great pestilence that periodically appeared in the Mexican Basin during the years 1520-1610 was epidemic typhus (Rickettsia prowazekii). His conclusion was based on descriptions of the disease available to him at the time and his knowledge that the human body louse (Pediculus humanus corporis) may have been an Old World ectoparasite. He suggested that typhus could

${ }^{5}$ Lovell, op. cit., note 4 above, pp. $426-42$.

${ }^{6}$ Charles Gibson, The Aztecs under Spanish rule, Stanford University Press, 1964, Appendix IV, Epidemics, pp. 448-51.

${ }^{7}$ Hanns J Prem, 'Disease outbreaks in Central Mexico during the sixteenth century', in Noble D Cook, W George Lovell (eds), "The secret judgments of God": Old World disease in colonial Spanish America, Norman and London, University of Oklahoma Press, 1992, pp. $20-48$.

\footnotetext{
${ }^{8}$ Charles Gibson, Tlaxcala in the sixteenth century, Stanford University Press, 1967, pp. 138-43.

${ }^{9}$ Prem, op. cit., note 7 above, p. 42.

${ }^{10}$ A Rómero, 'Dos cartas ineditas del P. Bernabe Cobo', Revista histórica tomo VIIIentregas I-III. 1925, Lima, Instituto histórico del Peru, pp. 26-50.

${ }^{11}$ Nicolle, op. cit., note 2 above; Zinsser, op. cit., note 3 above.
} 


\section{John S Marr and James B Kiracofe}

have made a transatlantic passage in the galleons. However, the signs and symptoms available for his critique were few: fever, abdominal pain, bleeding from the nose and a net-like rash. He inferred that whatever the disease may have been, it was an Old World importation, conferring selective immunity on Spanish colonists and African slaves. He separated the disease's presentation from smallpox and measles (which were well known to Spanish recorders at the time) and dismissed less likely infections such as endemic typhus, plague, yellow fever and spotted fever. Zinsser's conclusions are often cited by medical historians as proof that the great pestilence was epidemic typhus. ${ }^{12}$ In fact, he only suggested epidemic typhus as the best available candidate, given the paucity of information available to him. His argument that the more serious epidemics in post-contact Mexico were due to this disease should be re-examined carefully. Unfortunately, he often omitted primary references, using secondary citations, beginning with the Spanish historian, Joaquín Villalba, who wrote his account over two hundred years after the epidemic in $1802 .{ }^{13}$ Zinsser quoted Villalba as having "derived much of his information from a work in the title of which the word 'tabardillo' is first applied to the disease. It is De febris epidemicos, et novos quoslatine punticularis [sic], vulgo tabardillo et pintas dicitur, natura, conditione et medela". This treatise, whose correct title is De febris epidemicae, et novae quae latine puncticularis, was published in 1574 and attributed by Nicolás Antonio and Alberto de Haller to Alonso de Torres writing at the instigation of the marqués Don Luis de Astuñiga y Avila, although Villalba himself said the author was Luis de Torres. These citations deal with the Old World epidemics and may document the emergence of typhus fever. Villalba's suggestion that the disease was New World "tabardillo" (or "tabarete") was solely based on a work published in 1570 by Dr Francisco Bravo entitled Opera medicinalia, in quibus quam plurima extant scitu medico necessaria. Zinsser quotes Villalba as saying he would give: "the description of this disease, causes, signs, and symptoms and cure" at the proper time. ${ }^{14}$ But he omitted to do this. Zinsser made no comment on Nicolle's smallpox theory.

Zinsser explored the possibility that the disease existed in Mexico before contact with the Spanish invaders. He cited the discoveries of New World rickettsiosis (endemic typhus, spotted fever) as examples, and referred to another rickettsiologist, Hermann Mooser, who "is inclined to believe that the disease [typhus] existed in Mexico before the arrival of the Spaniards". ${ }^{15}$ Citing pre-contact evidence that the head louse had been found in southwestern American mummies, he noted that "bags of lice" were given to Montezuma as tribute. Later, he admitted that the insects were cochineal bugs, used to make dyes. He hypothesized that epidemic typhus-either imported or endemic - might conceivably have been maintained in various rodent

\footnotetext{
${ }^{12}$ See Willian H McNeill, Plagues and peoples, New York, Anchor Books Doubleday,1976; Erwin H Ackerknecht, History and geography of the most important diseases, New York, Hafner, 1965; Kenneth F Kiple (ed.), Plague, pox and pestilence, New York, Barnes \& Noble, 1997; and Ann F Ramenofsky, Vectors of death: the archeology of European contact, Albuquerque, University of New Mexico Press, 1987.
} 


\section{Was the Huey Cocoliztli a Haemorrhagic Fever?}

populations. He ignored mice as potential reservoirs, focusing on rats, but then concluded that other rat genera could have offered a reservoir nidus. (This observation of a non-human reservoir for epidemic typhus was validated forty years later when $R$. prowazekii was found in North American flying squirrels. ${ }^{16}$ )

Actual physical descriptions of the 1576-80 epidemic used by Zinsser to substantiate his theory are surprisingly brief: "The symptoms were congestion (pujamiento), fever, bloody stools, blood from the nostrils" and, "Matlatl signifies net, and zahuatl eruption, or spots, which means an eruption arranged in the form of a net". Although Zinsser was undecided about whether epidemic typhus was the cause of this epidemic, many subsequent historians have interpreted his proposal as fact. Yet, re-reading his final statement, it is clear he was unsure: "It is quite impossible to decide with certainty whether typhus was one of the gifts bestowed, with other things, by Europe upon the Western Hemisphere. But in coming to this conclusion we have learned a number of interesting facts." ${ }^{17}$ Although Zinsser had access to disease descriptions, he did not comment on ecological and epidemiological factors surrounding the huey cocoliztli. The mode of transmission and the incubation period were unknown, and attack rates were unavailable (although overall Indian mortality was very high). In addition, information on seasonality, climatological risk factors, descriptions of local societal, food and agricultural factors were also not available to him. Since his publication, many new facts, as well as new disease entities, have become apparent.

In 1992, Hanns Prem cited numerous primary and secondary sources relating to the epidemic. ${ }^{18}$ In his study of sixteenth-century Mexican epidemics he stated, "Indian sources report unanimously that, as in the sickness of $1545-48$, the most striking symptom of the epidemic was bleeding from the mouth and nose, in addition to hemorrhaging from the ears, eyes, and vagina, as well as bouts of bloody diarrhea." He also cited the Spanish friar Jerónimo de Mendieta (a Franciscan missionary and chronicler of early colonial New Spain), who referred to a "great bloodiness". He interpreted this to be "blood flowing from the nose", ${ }^{19}$ then cited the Codex Florentino, noting that additional symptoms also included bleeding from the eyes, ears, vagina and anus: "It came to pass ... that a great sickness came to be prevalent known as a plague. From people's noses blood issued; there was much death everywhere. ${ }^{20}$ Prem also based his descriptions on primary sources, and noted that

${ }^{16}$ F M Bozeman, S A Masiello, M S Williams, et al., 'Epidemic typhus rickettsiae isolated from flying squirrels', Nature, 1975, 255: 545-7.

${ }^{17}$ Zinsser, op. cit., note 3 above, p. 254.

${ }^{18}$ Prem, op. cit., note 7 above, pp. 38-42. Earlier, on page 32 Prem cited the Codex Aubin, (also called Codice de 1576) which is a Nahuatl text illustrated with marginal images painted in colour. On page 117 of the original there is a drawing of an Indian with large drops of blood flowing from the nose. The accompanying text in Nahuatl speaks of tribute payments made on "today, Saturday the 18 of August" and adds “.... and also in August the sickness continued.
Blood came out of our noses. Only in our houses did the priests take our confessions and they helped us to eat. And the doctors cared for us. And when the church bells rang they did not sound for the buried, for we were abandoned in the church." See Charles E Dibble (translator), Historia de la nación mexicana: reproducción a todo color del Codice de 1576 (Codice Aubin), Madrid, Ediciones José Porrua Turanzas, 1963. (The translation is from Nahuatl into Spanish, the English passages above are our translation of Dibble's Spanish transcription.)

${ }^{19}$ Prem, ibid., p. 39.

${ }^{20}$ Ibid. 


\section{John S Marr and James B Kiracofe}

the 1576 sickness included both Spaniards and Africans, information evidently unknown to Zinsser.

In 1956, Germán Somolinos d'Ardois published in Mexico a remarkable discovery made several years earlier by Dr J Tudela de la Orden in the Archivo del Ministerio de Hacienda in Madrid. ${ }^{21}$ This sixteenth-century document, written by the Spanish physician, Francisco Hernández, provided important, carefully described additional symptomatology of the huey cocoliztli. Using other rare primary sources, Somolinos d'Ardois created a helpful context for understanding the importance of Hernández and his work, which was thought to have been lost. Present in Mexico City in 1576-77 and working in the Royal Hospital, Hernández held the title of Protomédico de su magestad de todas las Indias, or roughly rendered, "His Majesty's Doctor for the Indies", meaning all Spanish possessions in the New World. He personally advised the Viceroy and directed the official public health intervention during the epidemic. Another witness, Alfonso López de Hinojosos, a doctor working under Hernández's direction at the time, wrote a book entitled Summa y recopilación de chirugia, published in Mexico by Antonio Ricardo in 1578, with a second edition published by Pedro Balli in 1595. López de Hinojosos commented that

... the remedies of the most famous doctors, appearing not to be satisfactory, the very Excellent Lord Viceroy ordered that anatomical studies be conducted. Because the Royal Hospital was most cool and accommodating ... and because there were regularly at that time more than two hundred patients there, it was there that they made the anatomical studies, and I myself with my own hands made them in the presence of Dr. Francisco Hernández, His Majesty's Chief Doctor, and having made these anatomical studies I gave notice to His Excellency. ${ }^{22}$

Somolinos d'Ardois further explained that the description given by Hernández was based on his personal observation made in the Royal Hospital, as well as in the homes of the sick during visits to affected areas, and during the "very many" autopsies that López de Hinojosos performed in his presence. Somolinos d'Ardois believed that Hernández's eyewitness description of the symptoms and treatments of the illness he saw and treated, written in a curious, idiosyncratic, grammatically flawed Latin, tinged with Greek, was not the version intended for the Viceroy or even for doctors practising in Mexico. Rather, Somolinos d'Ardois believed that this version was intended to present this unfamiliar disease to European doctors in a monograph or as a chapter of an unpublished book commenting on Galen, which he was known to be preparing. As Somolinos d'Ardois pointed out, both Hernández and López de Hinojosos were quite familiar with typhus, smallpox, and other European epidemic diseases, yet neither of them ever used the Spanish terms for

\footnotetext{
${ }^{21}$ Germán Somolinos d'Ardois, 'Hallazgo del manuscripto sobre el Cocoliztli original del Francisco Hernández', in Enrique Florescano and Elsa Malvido (eds), Ensayos sobre la historia de las epidemias en Mexico, 2 vols, Mexico, Instituto Mexicano del Seguro Social, 1982, vol. 1, pp. 369-81. (Originally published in Prensa Médica Mexicana, 1956, 21 (7-10): 115-23.)
}

\footnotetext{
${ }^{22}$ Ibid., p. 370 . For an illuminating exposition of the state of medical practice in sixteenthcentury Mexico, see John Tate Lanning, Pedro de la Torre, doctor to the conquerors, Baton Rouge, Louisiana State University Press, 1974; pp. 6-8 describe the role of the Protomédico.
} 


\section{Was the Huey Cocoliztli a Haemorrhagic Fever?}

these well-known illnesses to describe what they saw in the huey cocoliztli outbreak. The use of the Nahuatl term "cocolistle" by López de Hinojosos and Hernández's apparent intention to present an unfamiliar disease to his European colleagues strongly suggest that what they witnessed in Mexico in 1576 was something previously unknown to them. Somolinos d'Ardois summarized previous explanations (haemorrhagic influenza, yellow fever, leptospirosis, other viral infections, malaria, typhus and typhoid) and explained why none of them fits the description rendered by Hernández, concluding that even with many readings of this newly discovered source he was not able to identify conclusively the illness at that time. He repeated the various prevailing theories and their problems, and stated that he hoped further research then in progress would ultimately reveal the identity of the pathogen. ${ }^{23}$ Fourteen years later, in 1970, Somolinos d'Ardois concluded that the cocoliztli was a "viral process of hemorrhagic influence", a result of many different, confluent infectious processes. ${ }^{24}$

The following is our translation of a relevant excerpt of Dr Hernández's account from the Spanish translation that Somolinos d'Ardois published with the original Latin text:

The fevers were contagious, gripping and continuous, very much a total pestilence and in great part lethal. The tongue, dry and black. Intense thirst, urine the colour sea green, leafy green, and black, and from time to time changing from a greenish to a pale colour. Pulse frequent and rapid, but small and feeble, sometimes almost none. The eyes and all of the body yellow. Following (these symptoms) delirium and convulsions. (There appeared) pustules behind one or both ears, and hard and painful tumours, pain in the heart, chest and stomach, trembling and great anxiety and dysentery; the blood, which flowed from a cut vein was the colour green or very pallid, dry and without any serosity. In some gangrenes and lesions erupted on the lips, the pudenda and other areas of the body with members putrefied, and blood flowed from their ears; in truth, in many people blood flowed from the nose. Of those who relapsed practically none survived. With the flow of blood from the nose (if it was promptly stopped) many recovered, the rest perished. Of those attacked by dysentery (if they would take the medicine), the majority usually survived; nor were the abscesses behind the ears mortal, if in some way they receded, or spontaneously came to a head, or if caustic substances were used to make openings [then] even from unripe abscesses the liquid part of the blood ran out, or the pus was removed, after which the cause of the sickness was also eliminated. Moreover, of those who urinated with an abundant and pallid flow some (in autopsy) showed a very swollen liver, the heart black, from which flowed a pallid (yellow) liquid and then black blood, the spleen and the lungs, black and semi-putrefied, bile could be seen in its own place, the stomach dry and the rest of the body, for any part that was cut, extremely pallid. This epidemic attacked by preference the young and only rarely old people, who even when attacked by the sickness, frequently recovered and were saved. This plague began in the month of June of 1576 and is not yet over in January when we write these lines. From this New Spain it invaded all cool regions in a perimeter of 400 miles and struck with somewhat less intensity the warmer regions. In those first invaded, [the disease] infested now these now those regions occupied by tribes of Indians, then the habitations of Indians and

\footnotetext{
${ }^{23}$ Ibid., pp. 377-9.

${ }^{24}$ Germán Somolinos d'Ardois, 'La epidemia de Cocoliztli de 1545 señalada en un códice', in
}

Florescano and Malvido (eds), op. cit., note 21 above, pp. 233-4. (Originally published in Tribuna Médica, 1970, 15 (4): 85.) 


\section{John S Marr and James B Kiracofe}

Africans, then the mixed populations of Indians and Spaniards, later still, the Africans, and now finally it attacks the Spanish settlements. The weather was dry and tranquil, even though there were earthquakes, the air was impure and cloudy, but the clouds did not resolve into rains, but converted themselves into a virtual incubator of putrefaction and corruption. ${ }^{25}$

Because this remarkable, eyewitness account was prepared by a trained, experienced physician, working within the framework of scientific practice and methodology as it existed in the 1570 s, the Hernández report is an invaluable source, and one of the best for understanding the possible cause of the 1576-80 outbreak. It is appropriate, therefore, to attempt a differential diagnosis based on Hernández's observations, although other supporting documents reinforce our conclusion (Table 2). This disease was obviously an acute, fulminant infection causing a high, unremitting fever, dehydration (intense thirst, tongue dry) and hypotension (pulse small, feeble, sometimes none). These symptoms by themselves might suggest many bacterial, viral or parasitic (malaria) infections. The addition of delirium and convulsions may have been due to a high sustained fever, primary central nervous system involvement, or both. Although any infectious process can, at times, cause an altered sensorium

\footnotetext{
${ }^{25}$ The following is Somolinos d'Ardois's Spanish rendering of the original Latin text, which we translated above into English (op. cit., note 21 above, p. 375): "Las fiebres eran contagiosas, abrasadoras y continuas, mas todas pestilentes y, en gran parte letales. La lengua seca y negra. Sed intensa, orinas de color verde marino, verde (vegetal) y negro, mas de cuando en cuando pasando de la coloración verdosa a la pálida. Pulsos frecuentes y rápidos, más pequeños y débiles; de vez en cuando hasta nulos. Los ojos y todo el cuerpo, amarillos. Seguía (a lo dicho) delirio y convulsión. (Aparecían) postemas detrás de una o de ambas orejas, y tumor duro y doloroso, dolor de corazón, pecho y vientre, temblor y gran angustia y disenterías; la sangre, que salia al cortar una vena, era de color verde o muy pálido, seca y sin ninguna serosidad. A algunos gangrenas y esfacelos invadían los labios, las partes pudendas y otras regiones del cuerpo con miembros putrefactos, y les manaba sangre de los oídos; a muchos en verdad fluíales la sangre de las narices. De los que recaían casi ninguno se salvaba. Con el flujo de la sangre de las narices (si era oportunamente detenido) muchos se salvaban, los demás perecian. Los atacados de disentería (si acontecía que acatasen la medicación) en su mayor parte ordinariamente se salvaban, ni los abcesos detrás de las orejas eran mortales, si en modo alguno retrocedisen, sino que esponáneamente, maduraran, o dada la salida con los cauterios por los agujeros, aún de los abcesos inmaduros fluyese la parte líquida de la sangre, o se eliminara el pus, tras de lo cual quedaría también eliminada la causa de la
}

enfermedad. Además, quienes orinaban con micción abundante y pálida, partidos (en la autopsia) mostraban el hígado muy hinchado, el corazón negro, manando un liquido pálido (amarillo) y después, sangre negra, el bazo y el pulmón, negros y semi putrefactos; la atrabilis podía ser contemplada en su vasija, el vientre seco y el resto del cuerpo, por cualquiera parte que fuese cortado, palidísimo. Esta epidemia atacaba preferentemente a los jóvenes y rara vez a los viejos, quienes aún invadidos por ella, frecuentemente lograban vencerla y salvarse. Comenzó tal peste en el mes de junio de 1576 y no ha terminado en enero cuando trazamos estas líneas. De esta Nueva España invadió todas las regiones frías en un perímetro de $\mathbf{4 0 0}$ millas y trató con algún mayor miramiento (es decir atacó algo menos) las regiones más cálidas, infestando en las invadidas primeramente ora estas ora aquellas regiones ocupadas por las tribus indias, después, las habilitadas por indios y etiopes, luego las de población mixta de indios y españoles, más tarde todavía, las de etiopes y ahora, finalmente ataca las de españoles. El tiempo era seco y tranquilo, aunque turbado por sismos; el aire, impuro henchido de nubes, que, empero, no se resolvían en lluvias, convirtiéndose en verdadero semillero de putrefacción y corrupción." There follows more concerning how the Indians were treated and how the treatments did or did not help. The treatments were mostly based on native herbology, and the specific plants are named. The decoctions were put into the stomach with tubes, other ointments were applied to the skin. Doses and frequency are specified. 


\section{Was the Huey Cocoliztli a Haemorrhagic Fever?}

(trembling, great anxiety), it is less common in smallpox, but often found with typhus (the word derives from the Greek for smoke, i.e. confusion) and typhoid fever. Another sign inferred from the passage is massive intravascular haemolysis-a destruction of red blood cells (RBC)-significant enough to thin the blood (blood very pallid, body extremely pallid), tinge the sclera and skin (the eyes and all of the body yellow), and cause the urine to change colour from amber, to light green, to dark green (urine the colour sea green, leafy green), and eventually black due to massive RBC destruction and the direct bilirubin by-products of this. Although these symptoms are characteristic of severe falciparum malaria (black water fever), yellow fever, and dengue haemorrhagic fever, no one has seriously suggested these arthropod borne diseases as viable candidates. Neither smallpox nor epidemic typhus are characterized by intravascular haemolysis. In addition, spontaneous bleeding (blood flowing from the ears and nose, and dysentery) suggests that platelets and, perhaps, other coagulation products were also consumed, giving rise to either thrombocytopenic purpura (spontaneous subcutaneous bleeding due to lack of platelets) or a disseminated intravascular coagulation (DIC) syndrome (spontaneous bleeding from the circulatory system into all organs of the body). Once coagulation is compromised, spontaneous haemorrhage occurs throughout the body and into organs (swollen liver, heart black, spleen and lungs black and semi-putrefied). Extremities, lacking oxygenated blood, become gangrenous (gangrenes and lesions erupting on the lips, the pudenda and other areas of the body with members putrefied).

The reference to "abscesses behind the ears" suggests either inflammation of the post auricular lymph nodes or infection of the mastoid processes. Enlarged lymph nodes in the axillae, neck and groin are not mentioned. The observation that drainage of blood and pus from the abscesses increased survival rate is suggestive of mastoidectomy, an operation used to drain infected spongy bone before the brain became secondarily infected. However, Somolinos d'Ardois refers to the "postemas detrás de las orejas", stating, "without any doubt" that they were suppurative parotid (salivary) glands.

Signs and symptoms do not include the characteristic progression of a rash, culminating in the umbilicate pustules which are the hallmark of smallpox. Similarly, the macular eruption of typhus fever, which spreads centrifugally, is not noted. While both these diseases can appear with minimal or no rash, it is the exception, and given the number of victims examined, some cases would have been noted. The spectrum of disease presentation for haemorrhagic fevers in general (which would include Old World Lassa fever), or New World arenaviral haemorrhagic fevers, are characterized by massive internal and external haemorrhage, as noted above, and a reddening (erythema) of the face. Other typical signs and symptoms include continuous fever, sweating, hypotension, tremor, convulsions, encephalopathy and shock. Haemorrhagic phenomena include nosebleeds (epistaxis), conjunctival suffusion (blood-shot eyes), vomiting of blood (haematemesis), bloody stool (dysentery), frank blood per stool (haematochezia), haematuria (blood in the urine), bleeding from the gums (gingival haemorrhage), and vaginal haemorrhage. These bleeding diatheses are due to severe thrombocytopenia (low platelets). 


\section{John S Marr and James B Kiracofe}

\section{Table 2}

Medical and epidemiologic observations of the 1576 epidemic

Chief Complaint:

Vital signs:

Skin:

Head, ears, eyes, nose throat (HEENT):

Cardiopulmonary:

Gastrointestinal:

Genito-urinary:

Neurological:

Other:

Post mortem:
Excess thirst, fever (c); headache, confusion/delirium (d).

Temperature: high $(\mathrm{a}, \mathrm{b}, \mathrm{c})$, continuous $(\mathrm{c})$.

Pulse: feeble/none (c); equal (d).

Net-like rash (a,d); gangrene of lips (c); yellow (c); petechial eruptions/scattered small black dots (d).

Nasal haemorrhage (a,b,c); bleeding from the mouth (b); bleeding from the eyes (b); bleeding from the ears (b); tongue dry, black (c); post-auricular pustules and abscesses (c); eyes (conjunctiva) yellow (c).

Lung congestion (a), hemoptysis (a); chest pain (c); pain over the heart (c).

Bloody stools (a); blood per rectum (b); stomach pains (b,c); bloody stool/dysentery (c).

Vaginal bleeding $(b, c)$; gangrene of the pudenda (c).

Trembling, anxiety (c); coma, coma-vigil, convulsions (d).

Great bloodiness (b); "Other body members putrefied" (c).

Liver: enlarged (c).

Heart: black in colour (c).

Lungs: black (c) stomach: dry (c).

Urine: green, black, then pale (c).

Epidemiology: June onset, lasting through January. The young preferentially affected; elderly often recovered. Higher attack rates in cooler areas; warmer areas less intensively involved. Attack rates from highest to lowest: local Indians, Indian/African habitations, mixed Indian-Spanish populations, African enclaves, Spanish enclaves.

Weather conditions: dry, tranquil. Air: cloudy and impure (c).

(a) Zinsser, op. cit., note 3 above; (b) Prem, op. cit., note 7, p. 42; (c) Hernández , op. cit., note 21 above; (d) León, op. cit., note 26 below.

Our analysis of Hernández's text led us to conclude that the disease he described must have been a haemorrhagic fever and not smallpox, typhus, or any of the infectious diseases routinely postulated in the literature up until now.

Table 2 summarizes disease signs and symptoms cited by Zinsser, Somolinos d'Ardois, and others. Note that the word "matlazahuatl" was never used by Zinsser in his descriptions of the 1545 or 1576 outbreaks; however, Nicolás León substantiated its presence, adding that "those suffering from this disease have their entire bodies stained with small black dots, distributed in a certain symmetrical fashion, appearing 


\section{Was the Huey Cocoliztli a Haemorrhagic Fever?}

as the knots of the weave of a net. The actual representation is a petechial eruption, in its characteristic form and distribution"26 (emphasis added).

\section{Agricultural Practices and Ecological changes under Spanish Rule}

The Spanish colonial regime introduced changes in agricultural practices that profoundly altered the local ecology and economies of Mexico. Many widelydispersed, indigenous pre-Columbian communities were systematically reorganized according to European notions: dispersed rural agrarian populations were concentrated into urbanized communities organized around newly-built churches. Although maize (corn) production continued along with other staples-amaranth, beans, squash and peppers-large-scale Old World wheat production was introduced to satisfy an ever-growing Spanish demand for European style bread. To ensure adequate supplies of wheat, the Spaniards attempted to impose a requirement for tribute payments in wheat. Although the policy could not be uniformly enforced, and was gradually phased out, it nevertheless put pressure on the Indian population to devote a significant portion of their agricultural production to wheat cultivation. Extensive crown grants to favoured Spanish colonists of land and labour (rendered by Indian labourers on a rotational basis in partial fulfilment of obligatory community tribute payments) promoted establishment of large-scale wheat production. As Crosby noted, "by 1535 Mexico was exporting wheat to the Antilles and Tierra Firme, by mid-century bread in Mexico City was 'as good cheape as in Spain', and by the last quarter of the century Atlixco Valley alone was producing 100,000 fanegas (156,200 bushels) of wheat a year."27

Concurrently, to stabilize the availability of maize for the native population, whose best farmland had been lost to Spanish landowners and speculators, the colonial administration sought to increase overall levels of maize production by means of rigorously-enforced regulations. According to Gibson, these "included ... the promotion of maize cultivation on community lands and the storage of maize in Indian towns for future sale." ${ }^{28}$ Related laws in effect prior to 1576 sought to discourage speculation and accumulation of maize; Indian surpluses were warehoused locally and under Indian control.

After the Aztec capital city, Tenochtitlan, was destroyed by Cortés and his Indian allies, vast quantities of timber were required for building a new Spanish seat of government. The pre-Columbian city had been built on an island in the midst of interlocking, brackish and fresh water lakes on the Valley floor. The new colonial capital was built literally on the ashes of the old. The massive amount of wood required for this undertaking, and for subsequent continuous expansion of the urban centre throughout the century, led to a rapid deforestation of surrounding mountainsides. This process was exacerbated by the growing demand for firewood

\footnotetext{
${ }^{26}$ Nicolás León, ¿¿Qué era el Matlazahuatl y qué el Cocoliztli en los tempos precolombianos y en la época hispana?', in Florescano and Malvido (eds), op. cit, note 21 above, Apendice documental 2 , vol. 1 , p. 383 .
}

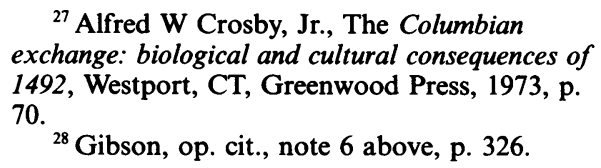

${ }^{27}$ Alfred W Crosby, Jr., The Columbian exchange: biological and cultural consequences of 1492, Westport, CT, Greenwood Press, 1973, p. 70 .

${ }^{28}$ Gibson, op. cit., note 6 above, p. 326. 


\section{John S Marr and James B Kiracofe}

and the steady pressure to bring more land into commercial agricultural production. When rapid storm water run-off from newly deforested areas caused silting, a rise in lake water levels, and consequent flooding, the colonial administration began a systematic programme of draining the lakes. The magnitude of the ecological changes rapidly brought about under Spanish rule were described by Gibson, who showed that:

... a complete drainage was never accomplished. But in dry seasons some of the predicted consequences of a complete drainage did come into being. The saline beds of Lakes Zumpango and Xaltocan were never agriculturally productive. Sub-surface alkaline waters continued to rise in drained areas and with their evaporation soils became impregnated with salts.... wherever the waters receded, the alkali proportionately advanced. Salinization was evident on the eastern shore of Lake Texcoco in the sixteenth century, where lagunillas had formed, where soils were alkalized, and where sterile years for crops were common. The first alkali dust storms occurred in the sixteenth century, and similar storms were regular features of the dry season during the rest of the colonial period. ${ }^{29}$

These "dust bowl" conditions were common, especially in drought years like 1576, and may have been conducive to an airborne spread of particulates even into areas of wheat production not directly affected by the drought.

\section{New World Arenaviral History, Phylogeny and Epidemiology}

The first North American arenavirus agent was described in $1970 ;{ }^{30}$ five years later its rodent reservoir ( $S$. hispidus) was discovered. ${ }^{31}$ Since then, a new Tacaribe complex virus has been discovered on an average of every three years resulting in the present total of fourteen New World arenaviruses. ${ }^{32}$ The phylogeny of arenaviruses is shown in Figure 1. Bowen and his co-authors have provided a taxonomic assignment of arenaviruses, including host and geographic distributions. ${ }^{33}$ They note that the genus Arenaviridae is composed of two serogroups/complexes, Old World and New World. The genetic characterization and phylogenetic analysis of the New World (Tacaribe) complex can be grouped into three lineages: A, B, and C. The phylogenetically similar group B includes five human pathogenetic viruses: Guanarito (GUA), Junin (JUN), Machupo (MAC), Sabiá (SAB) and Tacaribe (TCR); a sixth, non-pathogenic member is the Amapari (AMA) virus. All six group B viruses are of South American origin; four (GUA, MAC, JUN, and SAB) are associated with haemorrhagic disease outbreaks (TCR has caused illness in laboratory personnel; its potential for natural outbreaks is unknown). Five are hosted by the Sigmodontiniae sub-family of rodents (the TCR virus

${ }^{29}$ Ibid., p. 306.

${ }^{30}$ Charles H Calisher, T Tzaianbos, R D Lord, P H Coleman, 'Tamiami virus, a new member of the Tacaribe group', Am. J. trop. Med. Hyg., 1970, 3: 520-6.

${ }^{31}$ W C Winn, Jr, F A Murphy, 'Tamiami virus infection in mice and cotton rats', Bull. World Health Organ., 1975, 52: 501-6.

${ }^{32}$ Michael D Bowen, C J Peters, S T Nichol, 'The phylogeny of New World (Tacaribe complex) arenaviruses', Virology, 1996, 219 (1): 285-290.

${ }^{33}$ Michael D Bowen, C J Peters, and S T Nichol, 'Phylogenetic analysis of the Arenaviridae: patterns of virus evolution and evidence for cospeciation between arenaviruses and their rodent hosts', Molecular Phylogenetics and Evolution, Orlando, Academic Press, 1997, vol. 3, pp. 301-15. 


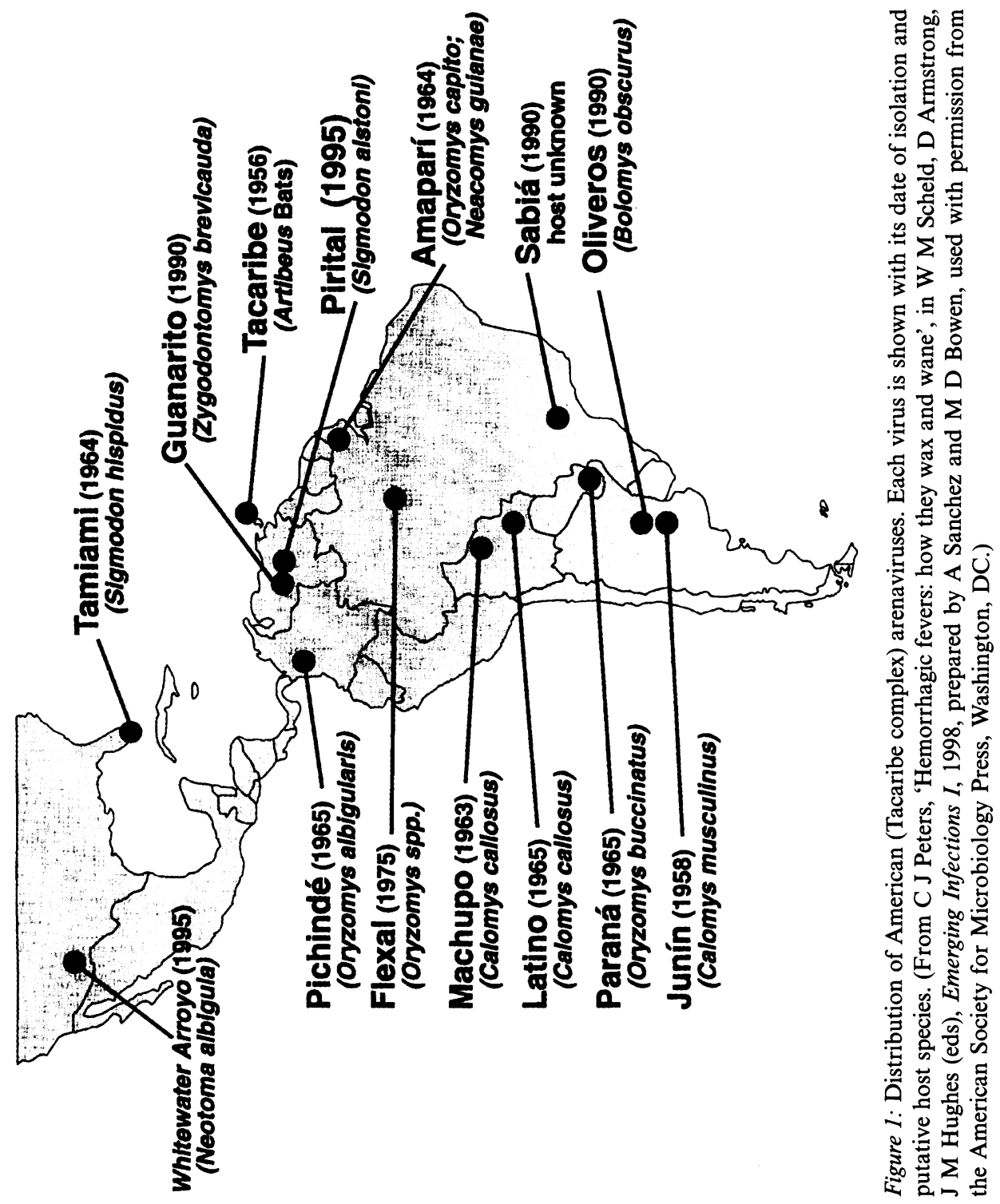




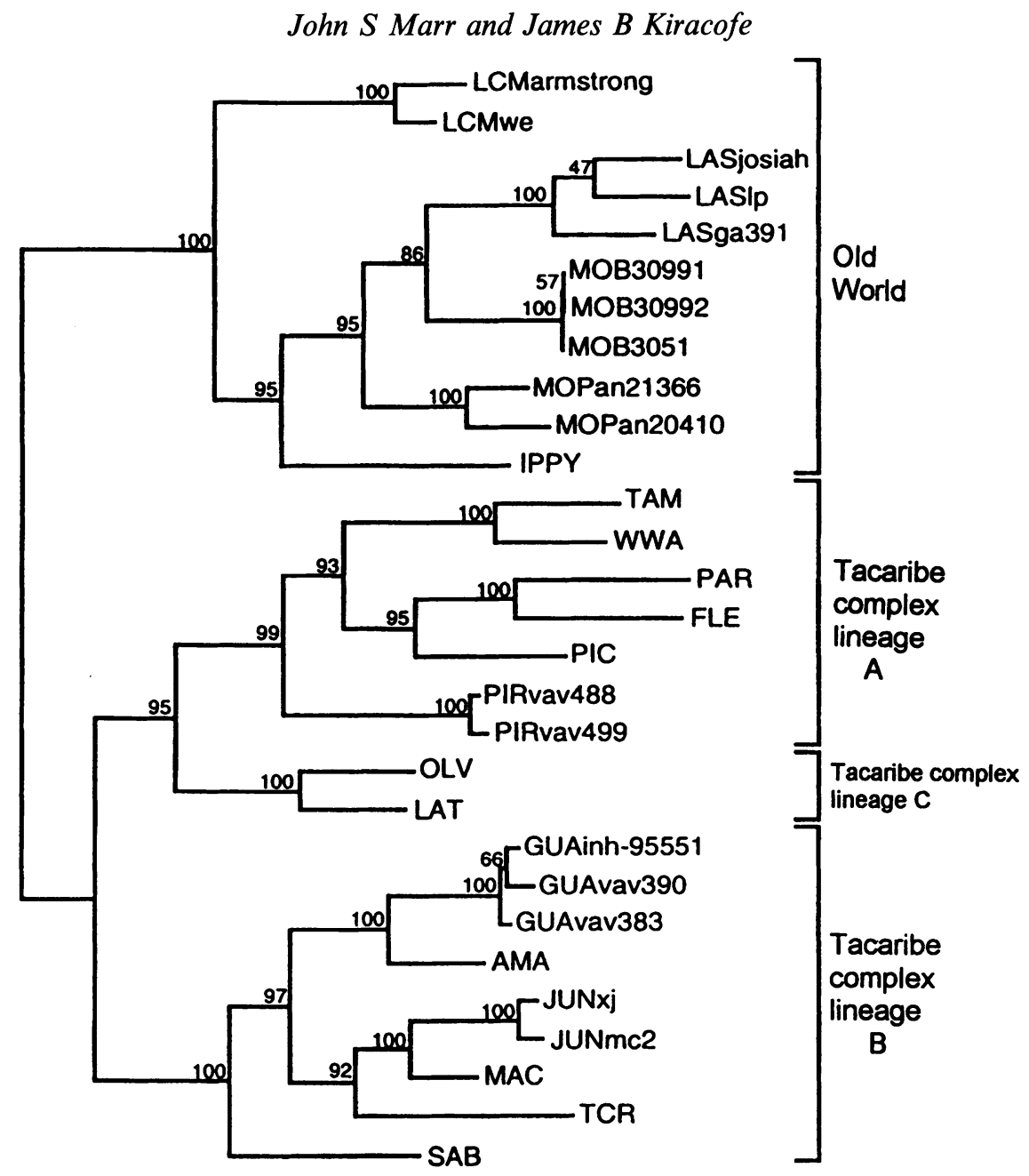

Figure 2: Phylogeny of arenaviruses estimated by maximum parsimony analysis of partial nucleocapsid gene sequences. Virus abbreviations: LCM, lymphocytic choriomeningitis; LAS, Lassa; MOB, Mobala; MOP, Mopeia; TAM, Tamiami; WWA, Whitewater Arroyo; PAR, Parana; FLE, Flexal; PIC, Pichinde; PIR, Pirital; OLV, Oliveros; LAT, Latino; GUA, Guanarito; AMA, Amapari; JUN, Junin; MAC, Machupo; TCR, Tacaribe; SAB, Sabiá. Strain names are indicated by lowercase text. The number to the left of each node indicates percent bootstrap support (1,000 replicates) for that node. Brackets indicate the clade of Old World arenaviruses and the three lineages within the Tacaribe comples. (From C J Peters, 'Hemorrhagic fevers: how they wax and wane', in W M Scheld, D Armstrong, J M Hughes (eds), Emerging Infections I, 1998, used with permission from the American Society for Microbiology Press, Washington, DC.)

is found in bats.) The six B lineage viruses are believed to be monophyletic, all having arisen from a common ancestor. Lineage A and B (New World) arenavirus distribution, dates of isolation and putative host species are depicted in Figure 2. The discovery of 


\section{Was the Huey Cocoliztli a Haemorrhagic Fever?}

arenaviral haemorrhagic fever in the 1950s was associated with changes in the harvesting of maize, which usually occurred between March and June. Rodent reservoirs reached high numbers and their urine and body parts became airborne during mechanical threshing and were inhaled. Routes of transmission among humans may have also occurred through infected dust and grain and by inoculation of viral particles through cuts and abrasions. In the 1950s, prior to its isolation in Bolivia in 1963, infection with the Machupo virus was referred to as "black typhus". Grassland rodents increased and became adapted to village houses and human habitations where rodent urine and saliva contaminated foods and eating surfaces. Epidemics of Guanarito haemorrhagic fever in Venezuela were associated with the clearing of grassland for agricultural planting and cattle ranching. Similarly, human habitats became infested with grassland rodent reservoirs of viral haemorrhagic fever, which replaced noninfected forest rodents. Although the rodent host of Sabiá haemorrhagic fever is unknown and natural outbreaks have not been identified, this virus has demonstrated its ability to spread through aerosol exposure in laboratory settings, and appears to have the same epidemic potential as the other three arenaviruses-an alteration of agricultural, farming or forestry practices.

Clarence Peters has recently summarized the epidemiology and distribution of the fourteen New World haemorrhagic fevers: "We also do not know how many arenaviruses there may be; one could speculate that eventually we may find a virus for every sigmodontine rodent species we adequately test, with more than 300 sigmodontine species now known." ${ }^{34}$ Given the wide geographical dispersion of New World arenaviruses and potential rodent reservoirs, the possibility of an as yet unidentified Mexican haemorrhagic fever strain exists.

Ecological factors contributing to New World arenaviral epidemics vary. Most of these, however, are intimately related to harvesting, changes in farm labour practices or peri-domiciliary exposure to rodents and their excreta. Contemporary information suggests that these haemorrhagic fevers occur when agricultural practices are changed or modified (as with the introduction of new crops, novel harvesting and storage practices, centralization of grain supplies), and potential rodent reservoirs are allowed to expand.

Fiona Reid lists 423 species and seventy-nine genera of the New World rats and mice (sub-family Sigmodontinae). ${ }^{35}$ Twenty-one genera and sixty-one species are found in southeast Mexico and Central America. Of these, at least five are widespread in the Central Valley of Mexico at elevations between 1000 and 2999 metres, including three Oryzomys rice rat species, the hispid cotton rat (Sigmidon hispidus), and vesper rat (Nyctomys sumichrasti). All these rodents consume seeds as a part of their natural diets. In particular, the hispid cotton rat, whose distribution extends from the southeastern United States, throughout Mexico, into Central America, northern Colombia and Venezuela, is considered a pest of sugar cane, rice and other crops. Seven species of

\footnotetext{
${ }^{34}$ Clarence J Peters, 'Hemorrhagic fevers: how they wax and wane', in W Michael Scheld, Donald Armstrong, James M Hughes (eds), Emerging Infections 1, Washington DC, American Society for Microbiology Press, 1998, pp. 17-25.
}

\footnotetext{
${ }^{35}$ Fiona A Reid, A field guide to the mammals of Central America and Southeast Mexico, New York, Oxford University Press, 1997.
} 


\section{John S Marr and James B Kiracofe}

bats are also present in Central America, five of which are found throughout Mexico, extending southward into Central America and northern South America. ${ }^{36}$

\section{Arenaviral Clinical Presentations versus Smallpox and Typhus}

Despite slight variations in clinical manifestations, the three epidemic New World arenaviral infections include high fever, sweating, malaise, headache, conjunctival injection, an exanthem on the thorax and flanks, petechiae, swelling of the face, neck and upper thorax, an exanthem on the palate, epistaxis, haematemesis, melena, haematuria, gingival haemorrhage, tremors, encephalopathy, slow pulse rate, hypotension, shock and thrombocytopenia. Case fatality rates range from 5 to 30 per cent. ${ }^{37}$

The above signs and symptoms as well as epidemiological settings are distinctively different from both smallpox and epidemic typhus. Historically, smallpox outbreaks occurred throughout the year in crowded circumstances where close person-to-person interaction fostered its spread. Epidemic typhus was associated with war and famine. The rashes of ordinary type smallpox and typhus differ in their early distribution on the body, their progression, and their physical description; both diseases also differ in complications and sequelae. With ordinary smallpox a macular exanthem appears on the face and forearms, and progresses centrifugally to involve the trunk, proximal and finally, distal extremities. Vomiting occurs in 50 per cent of cases; the rare haemorrhagic type produces heart failure, diffuse bleeding and bone marrow depression. Ordinary type smallpox mortality is approximately 60 per cent. ${ }^{38} \mathrm{Haem}$ orrhagic diatheses can occur in the haemorrhagic form of smallpox ( 1 per cent of cases), but are not typical in the ordinary type. The initial rash of epidemic typhus spreads to the trunk and extremities, becomes fixed, petechial and confluent. Complications include vascular collapse, renal failure and gangrene. Mortality can be as high as 60 per cent. Haemorrhagic phenomena can also occur in epidemic typhus, but are not usual. ${ }^{39}$

Table 2 summarizes the clinical and epidemiological information on the huey cocoliztli drawn from the primary and secondary resources cited previously. It was an acute, febrile illness suggesting disseminated intravascular coagulation with extensive internal and external haemorrhaging. A different diagnosis might include the rare (haemorrhagic) smallpox type or a severe form of epidemic typhus. However, there is ample evidence that the Spaniards and the Aztecs had a familiarity with smallpox and typhus. Before the huey cocoliztli, they both used specific words for smallpox (sarampión and hueyzahuatl) in their descriptions of the 1520-21, 1531-32 and 1563-64 epidemics (See Table 1). Similarly, the Spaniards described the 1545-48 epidemic as

\footnotetext{
${ }^{36}$ Ibid., pp.123-8.

${ }^{37}$ Abraham S Benenson (ed.), Control of communicable diseases manual, 16th ed., Washington, DC, American Public Health Association,1995, pp. 22-5; Clarence J Peters, 'Infections caused by arthropod- and rodentborne viruses', in Harrison's principles of internal medicine, 14th ed., New York, McGraw Hill, 1998, pp. $1132-45$.
}

\footnotetext{
${ }^{38}$ Fred Wang, 'Smallpox, vaccinia, and other poxviruses', in Harrison's Principles, op. cit., note 37 above, pp. 1095-6.

${ }^{39}$ David Walker, D Raoult, P Bruoqui, T Marrie, 'Rickettsia, mycoplasma and chlamydia' in Harrison's principles, op. cit., note 37 above, pp. 1048-9.
} 


\section{Was the Huey Cocoliztli a Haemorrhagic Fever?}

tabarillo (typhus), while Aztec used the unmodified cocoliztli. Whatever the great pestilence (huey cocoliztli) of 1576 may have been, it was unique and extensive in nature. After more than fifty years of exposure to Old World infections, it could be presumed that the people in the Central Valley had gained immunity as a result of previous welldescribed epidemics of these diseases. The huey cocoliztli epidemic began in the summer months, which was atypical for smallpox or typhus, and mainly affected the indigenous people, but also extended to Africans and Spaniards. This selective attack rate suggests either complete or partial immunity to the disease - a favoured hypothesis explaining the lack of cases among the Spaniards was their previous contact with smallpox or typhus - or a more intimate proximity to an infectious source, as would have been the case for Indian labourers if a haemorrhagic fever virus was the cause. Infectious airborne fomites from rodent excreta would be produced during the process of harvesting grain and its storage. Arenaviral contamination of grain supplies by rodents attracted to a new, centralized food source would have been highest for those people intimately involved in cutting, sifting, raking and collection for storage. Overseers and managers would not have been exposed to aerosols of infected dusts or grain, nor would they have lived in houses which might have attracted local rodents. Since most arenaviral haemorrhagic fevers are primarily due to airborne exposure, with minimal secondary cases, the indigenous people most likely to have been infected would have been workers, independent of their prior immunity. Secondary cases may also have occurred due to intimate contact with primary cases-as is the case today in crowded household settings and hospitals which lack appropriate isolation facilities.

In the 1950s initial accounts of outbreaks of A and B haemorrhagic fevers were reported during the harvest season after significant changes in agricultural practices had been made. A haemorrhagic fever affected farmers in wheat fields filled with dust from newly mechanized reaping processes, while B outbreaks had a peridomiciliary foci, when field rodents were attracted into farmers' houses. Ecological changes fostered Guanarito outbreaks and were also associated with an increased rodent population. The common element among these outbreaks was exposure to either airborne or ingested rodent excreta containing virus particles. Radical changes in agrarian practices fifty years ago were similar to those instituted by the Spanish in sixteenth-century Mexico. The possibility that a haemorrhagic fever virus may have been responsible for the huey cocoliztli is a logical alternative hypothesis to smallpox and typhus, when the tumultuous changes in agrarian practices and the ecology of the region are considered.

\section{Conclusion}

In summarizing present-day American arenavirology, Peters notes, "Imagine, for example, a haemorrhagic fever in Kansas or Nebraska killing corn harvesters and others in agricultural pursuits; the virus causing the fever would not be an avoidable virus for the people of the region, because they work in the most fertile area of the United States and provide products very important for foreign trade." ${ }^{40}$ Peters' opinion

\footnotetext{
${ }^{40}$ Peters, op. cit., note 34 above, p. 17.
} 


\section{John S Marr and James B Kiracofe}

is based on a growing body of knowledge about the extent of these New World viral infections. Less than ten years ago another mysterious disease due to a Hantavirus was first recognized in the southwestern United States. Although unrelated to arenaviruses, the Hantaan-related viruses (family Bunyaviridae) are also transmitted by exposure to rodent excreta and, at times, cause hemorrhagic fever epidemics. Hantaan-related viral infections are now recognized throughout the world as a major cause of morbidity and mortality. (It is estimated that Hantaan virus accounts for over 100,000 cases of disease each year in China. ${ }^{41}$ ) Prior to isolation of the new Hanta virus (now known as Sin Nombre), evidence of previous visitations was scant. Inexplicable Native American tales of mysterious deaths following bountiful piñon nut crops can now be explained by an increase in rodent populations. Today we know that Hantaan-related viral infections have been ancient and frequent causes of epidemics worldwide, always associated with rodent exposure and changes in their ecological niches.

The huey cocoliztli was responsible for the deaths of millions of indigenous Mexican people. The archbishop of Mexico, writing to the king of Spain, estimated that over half the Indian population died; Juan de Torquemada estimated the total deaths to be in excess of two million. While these estimates are less that the twenty-five million deaths attributed to the 1347-51 Black Death in Europe nearly two centuries before, the mortality rate of 50 per cent is similar. Precise scientific information as to its cause may never be found; however, its impact clearly altered the history of Mexico, if not the New World. Until recently, written records were largely lacking to substantiate the extent, aetiology and circumstances surrounding the 1576-80 epidemic. We have summarized various medical and historical accounts, and the data strongly suggest that this epidemic was due to an unknown agent which induced numerous haemorrhagic phenomena, not unlike those seen in present-day viral haemorrhagic fevers. No Old World disease known at that time fulfils the symptomatology or corresponds to local ecological and environmental changes that were occurring under Spanish rule. We propose that an as yet unknown arenavirus may have been responsible for various localized post-Columbian Mexican epidemics. Changes imposed upon indigenous agrarian practices, already altered by agricultural intensification and ecological events, may have fostered an intermittent appearance of a "new disease", finally culminating in the huey cocoliztli. Indigenous rodent populations (potential reservoirs for a haemorrhagic fever virus), whose nidalities were altered by a change in land practices and the attraction to new, alternative food supplies (wheat), may have caused a new infectious process in humans. Concentration of previously dispersed rural populations in new towns centred around churches, the centralization of food supplies, changes in crop production in concert with ecological events (deforestation, droughts, dust storms) may have fostered selective disease spread among the indigenous peoples and largely spared the Spanish colonists. Large-scale depopulation led to a destruction of local agrarian infrastructures which fostered and sustained these epidemics, and disease foci receded and then disappeared. Definite proof is unlikely, but the debate among

${ }^{41}$ James W LeDuc, J E Childs, G E Glass, and A J Watson, 'Hantaan (Korean Hemorrhagic Fever) and related rodent zoonoses', in Stephen S
Morse (ed.), Emerging viruses, New York, Oxford University Press, 1993. 


\section{Was the Huey Cocoliztli a Haemorrhagic Fever?}

anthropologists regarding New World disease origins might now be joined by other allied disciplines.

For the moment, our theory about the cause of the huey cocoliztli lacks positive scientific verification. We propose the following hypotheses which may validate or refute our proposal. State of the art immunologic methods might be able to identify nucleic acid fragments of arenaviruses (and, possibly, smallpox and epidemic typhus) in remains from documented victims of the huey cocoliztli. Studies of tissues, using polymerase chain reaction (PCR) molecular nucleic acid sequencing, might demonstrate arenaviral antigens. ${ }^{42}$ The eclectic sciences used in human paleopathologic studies might also offer new insights into remains of Amerindians known to have died during 1576-80. Evidence of haemorrhages into periosteal tissue would confirm an acute, fulminant haemorrhagic diathesis. PCR analyses of bone and marrow remains could also be examined ${ }^{43}$ These early efforts should not be extensive or expensive. If results from these studies suggest the existence of a haemorrhagic fever virus, similar technologies to recover Tacaribeviral antigens from sixteenthcentury rodent remains might then be employed and the results compared with the existing partial nucleocapsid gene sequence from the bank of existing arenaviruses.

Virologists and epidemiologists could then conduct screening tests using serosurveys among present-day Mexican rodents which might document yet unknown commensal arenaviruses capable of causing haemorrhagic fevers in humans (as Peters suggested). If confirmed, a more extensive series of in-depth epizootical studies could be performed similar to those recently reported on the Hantavirus. ${ }^{44}$ Such studies would include an analysis of macro- and micro-environmental factors: climate, rainfall, elevation, flora, soil, and indigenous rodent host biomes and nidalities. Traditional sero-epidemiologic studies among living Mexicans may confirm a low level endemicity of quiescent viral haemorrhagic fever diseases. It is also possible that a natural experiment proving our contention may also appear if changes in

${ }^{42}$ Larry E Bockstahler, P G Carney, G Bushar, J L Sagripanti, 'Detection of Junin virus by the polymerase chain reaction', $J$. Virological Methods, 1992, 39 (1-2): 231-5; Michael E Lozano, P D Ghiringhelli, V Romanowski, O Grau, 'A simple nucleic acid amplification assay for the rapid detection of Junin virus in whole blood samples', Virus Research, January, 1993, 27 (1): 3753.

${ }^{43}$ Arthur C Aufderheide and Conrado Rodríguez-Martín, The Cambridge encyclopedia of human paleopathology, Cambridge University Press, 1998.

${ }^{44}$ Martha C Monroe, S P Morzunov, A M Johnson, M D Bowen, et al., 'Genetic diversity and distribution of Peromyscus-borne Hantaviruses in North America', Emerging Infectious Diseases, 1999, 5 (1): 75-86; David M Engelthaler, D G Mosley, J E Cheek, C E Levy, et al., 'Climatic and environmental patterns associated with Hantavirus pulmonary syndrome, Four Corners region, United States', ibid., pp.
87-94; J N Mills, T L Yates, T G Ksiazek, C J Peters, and J E Childs, 'Long term studies of Hantavirus reservoir populations in the southwestern United States: rationale, potential and methods', ibid., pp. 95-101; Ken D Abbott, T G Ksiazek, J N Mills, 'Long-term Hantavirus persistence in rodent populations in Central Arizona', ibid., pp. 102-12; Amy J Kuenzi, M L Morrison, D E Swann, P C Hardy, and G T Downward, 'A longitudinal study of Sin Nombre prevalence in rodents, Southwestern Arizona', ibid., pp.113-117; Cherl A Pamenter, T L Yates, R R Parmenter, and J L Dunnum, 'Statistical sensitivity for detection of spatial and temporal patterns in rodent population densities', ibid., pp. 118-25; Charles H Calisher, W Sweeney, J N Mills, and B J Beaty, 'Natural history of Sin Nombre virus in Western Colorado', ibid., 126-34; James N Mills, T G Ksiazek, C J Peters, J E Childs, 'Long term studies of Hantavirus reservoir populations in the Southwestern United States: a synthesis', ibid., pp. 135-42. 


\section{John S Marr and James B Kiracofe}

present-day agricultural practices in Mexico occur and precipitate a new outbreak of haemorrhagic fever similar to those in Bolivia, Argentina and Venezuela over the last fifty years. If cases of such a disease were suddenly to appear, serologic studies for routine pathogens (yellow fever and dengue) might also include an arenaviral panel of known or putative viruses.

Independent of these suggestions, all of which require time, money and commitment, our proposal might receive further input from the robust Internet correspondence on pre-Columbian and colonial Mexican history. The many high quality on-line sites devoted to this subject might contribute additional insights and commentaries which could lead to new interpretations.

In closing, we would like to suggest that orthodox anthropologists consider the relatively recent discovery of New World arenaviruses in future research endeavours. The potential for Tacaribe epidemics in South America has been established. The more recent North American Hantaan virus studies might serve as models for future research on older outbreaks among New World, pre-contact, human populations. The discovery of these "new" viruses may also offer fresh insights and a reexamination of the many theories relating to other post-contact epidemics, which heretofore have been attributed to Old World importations. ${ }^{45}$

In the 1530s, a band of Spanish adventurers conquered the Inca Empire. It is commonly believed that some kind of epidemic devastated the Andes immediately prior to the Spanish arrival. Noble D Cook has advanced much evidence and argued strongly that this epidemic was of Old World origin, perhaps measles combined with pneumonic plague and influenza. ${ }^{46}$ However, if our hypothesis for the Mexican case-that some pre-existing New World viral disease became epidemic due to ecological changes brought about by large-scale and relatively sudden alterations of human agricultural practices-is valid, then perhaps the Peruvian case merits further study along these lines. A central feature of Inca policy for stabilizing food supplies in an often harsh highland zone of unpredictable harvests was the creation of agricultural terraces and the concentration of large food reserves of grain in specially constructed, garrisoned facilities strategically located along a system of roads the Incas had recently built. Until now, as Cook has most recently argued, it has been assumed that this affliction was an Old World disease brought to the New World by the Spanish. But is it possible that the Inca regime's vast public works programme, conducted during the relatively brief duration of their ascendency, created new ecological conditions favouring another, earlier epidemic of haemorrhagic fever? Only further research may provide the answer to this highly charged question.

\footnotetext{
${ }^{45}$ It would be presumptuous to make this statement without citing an expert source. Clarence J Peters commented on the antiquity of arenaviruses and their emerging potential to cause new disease: "Each arenavirus has a single rodent reservoir, implying a long evolutionary association with its host and suggesting a broad distribution wherever the rodent occurs ... We also do not know how many arenaviruses there may be; one could speculate that eventually we
}

\author{
may find a virus for every sigmodontine rodent \\ species we adequately test, with more than 300 \\ sigmodontine species known. Of the 15 \\ established American arenaviruses, the 4 \\ discussed here were initially isolated from patients \\ with severe hemorrhagic fever, but what is the \\ pathogenic potential of the ones known from \\ rodents?" Peters, op. cit., note 34 above, pp. \\ 20-1. \\ ${ }^{46}$ Cook, op. cit., note 4 above, p. 92.
}

